\title{
Properties of concrete containing construction and demolition wastes and fly ash
}

\author{
S. F. U. Ahmed
}

Dept. of Civil Engineering. Curtin University, Perth, Western Australia.

\begin{abstract}
This paper reports the properties of concrete containing recycled coarse aggregate (RCA) sources from local construction and demolition (C\&D) wastes and fly ash (FA) sourced from Western Australia (WA). The RCA is used as 25, 50, 75 and $100 \%$ (by wt.) replacement of natural coarse aggregate (NCA). In addition, the effect of $40 \%$ (by wt.) class F fly ash as partial replacement of cement on the properties of recycled aggregate concrete is also evaluated. The properties of concrete evaluated are the compressive strength, indirect tensile strength, flexural strength and water absorption. All properties are measured at 7, 28, 56 and 91 days. The results show that, better compressive, tensile and flexural strength of concrete containing $25 \%$ RCA as partial replacement of NCA can be obtained in recycled aggregate concrete. However, in the case of recycled aggregate concretes containing $40 \%$ fly ash the compressive strength at later ages such as at 56 and 91 days is increased but the indirect tensile and flexural strengths are decreased at all ages. It is observed that the water absorption is decreased as RCA content increased. It is also observed that the water absorption is decreased significantly in recycled aggregate concretes containing $40 \%$ fly ash at all ages.
\end{abstract}

\section{INTRODUCTION}

Sustainability of construction materials especially "concrete" is the most widely discussed topic in the world at present time and will continue in future as cement industries contribute significant amount of $\mathrm{CO}_{2}$ into atmosphere (Malhotra, 2002). The release of $\mathrm{CO}_{2}$ into the atmosphere due to cement production can be divided into two stages. One by the calcination of calcium carbonates and the other by the burning of coals to fuel the energy required during the cement production. While cement occupies only small portion of total volume of concrete, the coarse and fine aggregates occupy major portion approximately $75 \%$ to $80 \%$ of volume of concrete. The demand of aggregates and cement used in concrete is increasing worldwide every year due to rapid industrialisation and urban development. Yet there are worrying signs indicating the 
shortage of natural aggregates sources especially in large urban areas and this can cause scarcity problems in the future. On the other hand, vast amount of construction and demolition (C\&D) wastes are generated due to increased construction activities and demolition of existing structures and creates landfill problems worldwide. In one estimate, in Perth metropolitan area, the capital of Western Australia, it has been estimated that approximately 1.5 million tonnes of C\&D wastes were generated by the C\&D industry in 2000 (Wastenet, 2009). This waste was subsequently sent to landfill, accounting for almost $55 \%$ by weight. Due to increasing global awareness of environmental issues and climate change, the recycling of $C \& D$ wastes is expected to rise. Therefore, the use of $C \& D$ wastes in concrete should be a viable option for concrete industry which needs to be thoroughly researched before its potential application in concrete.

Fly ash is the byproduct of coal fired power plant and the disposal of this material also creates another environmental problem. The effects of fly ash on concrete are well established (Malhotra, 1990; 2002). The use of fly ash as partial replacement of cement imparts environmental benefits, reduces landfill demands, reduces concrete costs and improves concrete properties (Ravina and Mehta, 1986).

Significant amount of research on the use of recycled coarse aggregates (RCA) in concrete is conducted (Mandal, et al., 2002; Shayan and Xu, 2003; Zhang and Ingham, 2010; Yong and Teo, 2009; Tam et al., 2006; Yang et al., 2008; Xiao et al., 2005; Padmini et al., 2009; Debieb et al., 2010; Sagoe-Crentsil et al., 2001; Hansen and Narud, 1983). In most reported studies the RCA is obtained from known sources, such as concrete of known compressive strengths (Mandal, et al., 2002; Zhang and Ingham, 2010; Padmini et al., 2009), demolished reinforced concrete structures as the source of aggregates (Debieb et al., 2010; Sagoe-Crentsil et al., 2001; Xiao et al., 2005; Yang et al., 2008; Yong and Teo, 2009), etc. However, in reality the C\&D wastes are consisted of demolished concretes of various strengths, demolished masonry structures, and other demolished structures e.g. concrete pavements, runways, etc.. The manufacturers of recycled aggregates who collect the $C \& D$ wastes from different sources often received it in mixed form. Therefore, it is extremely difficult and not cost effective to the C\&D collectors to separate different components of C\&D wastes. In order to promote the use of locally manufactured recycled aggregates from $C \& D$ wastes in concrete industry in 
Western Australia the properties of concretes containing recycled aggregates need to be studied. The properties of concretes containing recycled aggregates obtained from $C \& D$ wastes will vary widely due to their diverse quality.

The use of RCA in concrete has been studied extensively and general trend is that it reduces the concrete's strength. The reduction of strength are commonly attributed to the old cement mortar adhered to the RCA. This old cement mortar is porous and contains microcracks due to stresses endured during its operable life and crushing process (Katz, 2004 and Etxeberria et al., 2004). It has also been suggested that the interfacial transition zone (ITZ) between the recycled coarse aggregate and cement matrix is the strength limiting phase (Otsuki et al. 2003) in recycled aggregate concretes. Hence, the quality of ITZ plays a significant role in the strength and durability of concrete containing RCA. The addition of supplementary cementing materials improves the ITZ, reduces porosity and improves the properties of recycled aggregate concretes (Corinaldesi and Moriconi, 2009).

While significant numbers of articles on properties of concrete containing RCA are available only a few studied the effect of supplementary cementing materials (SCM) in concrete containing RCA (Somna et al., 2012; Berndt, 2009; Corinaldesi and Moriconi, 2009; Tangchirapat et al., 2010; Kou et al., 2007a and 2007b). Somna et al. (2012) in their study measured the compressive strength and water permeability of recycled aggregate concrete containing ground fly ash. The RCA used in their study was obtained from crushing of cylinders tested in the laboratory. Slight improvement of compressive strength of recycled aggregate concrete containing $35 \%$ ground fly ash (by wt.) as partial replacement of cement is observed in their study. However, they noticed reduction in water permeability of recycled aggregate concrete containing ground fly ash. Tangchirapat et al. (2010) also reported similar improvement in compressive strength of recycled aggregate concrete containing high fineness fly ash. The RCA used in their study was also from the crushed test cylinders. Berndt (2009) studied the effect of partial replacement of cement with fly ash and slag on the properties of recycled aggregate concretes containing recycled coarse aggregate obtained from old RC slab. Kou et al. (2007a) studied concrete made with both fly ash and RCA obtained from commercial recycling facility which mostly contained recycled concretes. They found 
that both the replacement of cement with fly ash and the replacement of natural aggregate with RCA reduced the compressive strength of concrete. Lowering the water/binder ratio (W/B) compensated for the reduction. Others have also suggested that lowering the W/B ratio is a way of compensating the loss of strength in recycled aggregate concretes (Hansen and Narud, 1983). Others used fly ash as an addition rather than replacement in recycled aggregate concrete and found that this led to improved concrete performance (Poon et al., 2002 and Kou et al., 2007b). While all the above research on recycled aggregate concretes containing SCM used RCA obtained from known source of concrete structures/specimens, only one research studied the effect of SCM on the properties of concretes containing C\&D wastes (Corinaldesi and Moriconi, 2009) and reported improvement in compressive strength and other properties when fly ash and silica fume are used in the concretes. This paper presents the research results on certain mechanical properties of concrete containing coarse aggregates obtained from local C\&D wastes and locally available fly ash. This paper presents the results at various replacement levels of RCA on the compressive, indirect tensile, flexural strength and water absorption of concrete. The effect of $40 \%$ replacement of cement with class F fly ash on the above properties of concrete containing RCA is also evaluated in this study.

\section{EXPERIMENTAL PROGRAM}

The study is consisted of two parts. In the first part, the effect of RCA on the compressive, indirect tensile strength, flexural strength and water absorption of concrete is evaluated and in the second part, the effect of fly ash as partial replacement $(40 \%$ by wt.) of cement on the above properties of concrete containing RCA is evaluated. In each part five series of mixes having different contents of RCA are considered. Detail experimental program is shown in Table 1.

\section{Materials}

General purpose Portland cement was used in all mixes. The fly ash used in this study was class F fly ash and was obtained from Collie power station in Western Australia (WA). The properties and chemical compositions of fly ash and Portland cement is shown in Table 2. The recycled coarse aggregate was obtained from a local C\&D waste recycling plant in Perth, WA. Fig. 1 shows the analysis of contents of a $5 \mathrm{~kg}$ sample of the C\&D waste used as RCA in this study. The percentages are based on mass. It can be 
seen that approximately $65 \%$ are concrete and the rest consisted of masonry, tile, bitumen and others. Table 3 shows the properties of recycled and natural aggregates. Sieve analysis of RCA is also conducted and is shown in Fig. 2 (a). It is observed that the RCA used in this study met the requirements specified in Australian standard (AS 2758.1) except the sizes of 4.75 and $2.36 \mathrm{~mm}$. The natural coarse aggregates (NCA) used in this study were mixture of $10 \mathrm{~mm}$ and $20 \mathrm{~mm}$ in size. The sieve analysis of NCA is shown in Fig. 2(b). The NCA and RCA used in this study were in air dry condition before used in the mixing.

\section{Mix proportions}

Table 4 shows the mix proportions used to produce the test samples. The percentage replacements of NCA by RCA in Part A and NCA and Portland cement by fly ash and RCA respectively in Part B were weight percentages basis. The water/cement ratio is kept constant at 0.45 in all mixes.

\section{Casting, Curing and Testing}

The compressive strength, indirect tensile strength, flexural strength and water absorption were measured at four different ages (7, 28, 56 and 91 days) in each series. Slump test was done immediately after mixing the concrete to measure the workability of each mix. At least three specimens were cast and tested in each series. All specimens were water cured until the day before the test date. The compressive strength test was carried out on $100 \varnothing \mathrm{X} 200 \mathrm{~mm}$ cylinders and the indirect tensile strength was determined on $150 \varnothing$ X $300 \mathrm{~mm}$ cylinders. As for flexural strength, 100 X 100 X 400 $\mathrm{mm}$ prism was tested. The $100 \varnothing \mathrm{X} 200 \mathrm{~mm}$ cylinder was cut into three $50 \mathrm{~mm}$ thick slices and were used in water absorption test. All tests were conducted in accordance with relevant Australian standards.

\section{RESULTS AND DISCUSSION}

\section{Effect of RCA and fly ash on workability of concrete}

The measured slump values of all mixes are shown in Fig. 3. As expected the workability of the fresh recycled aggregate concrete is reduced with the increase of RCA content. The reduction in workability is caused by the high water absorption of RCA and the high content of fines in the RCA. As can be seen, the introduction of fly ash improves the workability of all mixes in Part B and this can be attributed to the 
lubricating effect of the fly ash due to its spherical shape. Also since a by weight replacement of fly ash was used and fly ash is less dense than cement there are more paste volume in the mixes which improves the workability.

\section{Effect of RCA on mechanical properties of concrete}

Figures 4-6 show the effect of RCA on the compressive, tensile and flexural strengths of concrete containing different RCA contents in part A. It can be seen in Fig. 4 that the replacement of $25 \%$ NCA by RCA (series 2) slightly increased the compressive strength at all ages. Similar results are also observed by other researchers (Yong and Teo, 2009; Tam et al., 2006). However, at higher replacement levels such as at 50\%, 75\% and $100 \%$ the compressive strength is decreased at all ages. The finding is consistent with others result of recycled aggregate concrete containing higher amount of RCA up to 100\% (Yang et al., 2008; Shayan and Xu, 2003; Yong and teo, 2009). The same phenomenon is observed in the case of tensile and flexural strengths with slight deviation in tensile strength at 28 days and flexural strength at 56 days in series 2.

The slight gain in strength of concrete containing 25\% RCA (series 2) is attributed to the remaining un-hydrated cement within the mortar on RCA. During the mixing process, the un-hydrated cement is activated and increased the strength of the concretes (Banthia and Chan, 2000). Another probability could be the presence of fines in the RCA (approx. 12\% measured in this study). The fines in the RCA reduced the watercement ratio (due to their higher specific surface areas and hence, higher water absorption capacity (Table 2)) and increased the compressive strength in series 2 . In addition, the beneficial results from $25 \%$ RCA may also from improved particle packing of the aggregates and the fine fillers of RCA. The fine fillers minimize the voids in concrete and improve the compressive strength (Jones et al., 2002 and 2003). At higher replacement levels (such as series 3,4 and 5), the fines in the mixes are also increased and reduced the amount of water available to complete the hydration reaction which can be seen from the slump values of the corresponding mixes (Fig. 3). This could be one of the reasons for significant reduction of strength in the mixes containing higher RCA contents. Nevertheless, the concrete containing 100\% RCA still exhibited about mean compressive strength of $32 \mathrm{MPa}$ at 28 days indicating its potential use as structural concrete. 
It should be noted in the above discussion that the observed strength gain of recycled aggregate concrete containing $25 \% \mathrm{RCA}$ and loss of strength at higher RCA replacement levels in this study is consistent with other studies where the RCA was sourced from reinforced concrete members or known grade of concrete. Therefore, the mixed C\&D wastes as RCA can be used in concrete. This finding will enhance the utilisation of $C \& D$ wastes in concrete without costly screening and separation processes involve in the manufacture of recycled aggregates.

Table 5 shows the relationship between the percentage of splitting tensile strength to compressive strength and compressive strength of concretes containing RCA and fly ash. It can be seen in the table that the recycled aggregate concretes with and without fly ash had maximum and minimum value between 6.5 and $11.0 \%$. Sageoe-Crentsic et al. (2001) reported that the tensile/compressive strength ratio of recycled aggregate concrete ranged from 8.9 and $12.1 \%$. Ravindrarajah and tam (1985) also reported that the splitting tensile strength of recycled aggregate concrete made with RCA and natural sand differed significantly from that of natural aggregate concrete. In this study, however, the incorporation of $40 \%$ fly ash did not change the splitting tensile strength of recycled aggregate concrete.

\section{Effect of RCA on water absorption of concrete}

The effect of RCA on the water absorption of concrete containing different RCA contents in part A can be seen in Fig. 7. It can be seen in the figure that, the water absorption of concretes containing RCA increases with increase in RCA contents at all ages. This is due to the higher water absorption of RCA measured in Table 2 and the adherence of old mortar in the RCA which is generally more porous than NCA.

\section{Effect of fly ash on concrete containing $R C A$}

The effect of replacement of $40 \%$ cement with fly ash on the compressive, tensile and flexural strength and water absorption of concrete containing RCA can also be seen in Figs. 4-7. It can be seen in Fig. 4 that the compressive strength of recycled aggregates concrete containing $40 \%$ fly ash is increased at 56 and 91 days. However, at early ages (such as at 7 and 28 days) the increase of compressive strength is not observed. This is due to the pozzolanic reaction of fly ash in the concrete. The long term strength gain of fly ash concretes is reported by many researchers. In the case of tensile and flexural 
strengths this phenomenon is not observed. However, the addition of fly ash shows dramatic improvement in water absorption of recycled aggregate concretes at all ages in this study. This could again be attributed to the pozzolanic reaction and the filling effect of fly ash in the recycled aggregate concretes.

From the test results it can be seen that the combined use of fly ash and RCA in concrete is feasible as long as the reduction in strength are accounted for in the design. Concrete mixes with RCA replacements of $75 \%$ and $100 \%$ are found to be unpractical due to poor workability. However, the workability can be improved by using fly ash or other SCMs and superplasticizer. This has already been observed in part B of this study where the replacement of cement with fly ash improves the workability by $50 \%$ and $30 \%$ of concrete containing $75 \%$ and $100 \%$ RCA, respectively. It should be noted that the RCA used in this research could also be greatly improved through screening to remove the fines and impurities, which might also help in improving the workability of recycled aggregate concrete. For 'green concrete' to become widely accepted as a substitute for conventional concrete quality control is essential to ensure consistent and predictable capacity. Further study is necessary considering other variables such as W/C or W/B ratios, varying fly ash contents and the use of admixtures. Further study also need to be conducted on the long term (beyond 91 days) behaviour of recycled aggregate concretes containing fly ash and other SCMs. It is also recommended to conduct an optimisation study to determine optimum RCA and fly ash contents and optimum mixture proportions.

\section{CONCLUSIONS}

Based on the limited study on the properties of concrete containing RCA sources from locally available construction and demolition (C\&D) wastes and class F fly ash, the following conclusions can be drawn:

- The workability of recycled aggregate concretes decreased with increase in RCA contents.

- Recycled aggregate concrete containing 25\% RCA exhibited improved compressive, flexural and tensile strengths. 
- Water absorption of all recycled aggregate concretes is increased with increase in RCA contents.

- The inclusion of fly ash improves the workability of recycled aggregate concretes.

- The addition of $40 \%$ fly ash significantly reduced the water absorption values of all recycled aggregate concretes.

- The addition of 40\% fly ash improved the long term (56 and 91 days) compressive strengths of recycled aggregate concretes.

The results presented in this paper within limited study demonstrate that structural grade concrete can be produced using mixed C\&D wastes as partial replacement of NCA together with partial replacement of cement by fly ash. This study shows that the difficulties in separation of constituents other than recycled concrete from C\&D wastes can be eliminated in the production of concrete. This will speed up the processing of RCA and at the same time reduce the processing cost of RCA. Further study need to be done to evaluate other engineering properties of this type of concrete for potential structural application.

\section{ACKNOWLEDGEMENTS}

Author acknowledges All Earth Group for donating the recycled aggregates and Fly ash Australia for donating the class F fly ash. Grateful acknowledgement is also due to final year project students Mr. Joshua Bruins and Mr. Tristan Iriks for their assistance in casting and testing of specimens in this study.

\section{REFERENCES}

Banthia, N. and Chan, C. (2000) Use of recycled aggregate in plain and fiber reinforced shortcrete. Concrete International, 2(6):41-45.

Berndt, M.L. (2009) Properties of sustainable concrete containing fly ash, slag and recycled concrete aggregate. Construction and Building Materials, 23: 2606-2613.

Corinaldesi, V. and G. Moriconi, (2009) Influence of mineral additions on the performance of $100 \%$ recycled aggregate concrete. Construction and Building Materials, 23: 2869-2876.

Debieb, F., Courard, L., Kenai, S. and Degeimbre, R. (2010) Mechanical and durability properties of concrete using contaminated recycled aggregates, Cement and Concrete composites, 32: 421-426.

Etxeberria, M., E. Vasquez, and A.R. Mari, (2006) Microstructure analysis of hardened recycled aggregate Magazine of Concrete Research, 58(10): 683-690.

Hansen, T.C. and H. Narud, (1983) Strength of recycled concrete made from crushed concrete coarse aggregate. Concrete International, 5(1). 
Jones, M.R., Zheng, L. and Newlands, M.D. (2002) Comparison of particle packing models for proportioning concrete constituents for minimum void ratio, Materials and structures, 35:301-309.

Jones, M.R., Zheng, L. and Newlands, M.D. (2003) Estimation of the filler content required to minimise voids ratio in concrete, Magazine of concrete research, 55(2):193-202.

Katz, A., (2004) Treatments for the Improvement of Recycled Aggregate. Journal of Materials in Civil Engineering, 16(6): 597-603.

Kou, S.C., C.S. Poon, and D. Chan, (2007a) Influence of Fly Ash as Cement Replacement on the Properties of Recycled Aggregate Concrete. Journal of Materials in Civil Engineering, 19(9): 709-717.

Kou, S.C., C.S. Poon, and D. Chan, (2007b) Influence of fly ash as a cement addition on the hardened properties of recycled aggregate concrete. Materials and Structures, (41): 1191-1201.

Malhotra, V.M. (1990) Durability of concrete incorporating high-volume of lowcalcium (ASTM class F) fly ash, Cement and concrete composites, 12(4): 271-277.

Malhotra, V.M. (2002) Sustainable development and concrete technology, Concrete International, 24(7).

Mandal, S., Chakraborty, S. and Gupta, A. (2002) Some studies on durability of recycled aggregate concrete. Indian concrete journal: 385-388.

Otsuki, N., S. Miyazato, and Yodsudjai, (2003) Influence of Recycled Aggregate on Interfly ashcial Transition Zone, Strength, Chloride Penetration and Carbonation of Concrete. Journal of Materials in Civil Engineering,: 443-451.

Padmini, A.K., Raamamurthy, K. and Mathews, M.S. (2009) Influence of parent concrete on the properties of recycled aggregate concrete, Construction and Building Materials, 23: 829-836.

Poon, C.S., Z.H. Shui, and L. Lam, (2002) Effect of microstructure of ITZ on compressive strength of concrete prepared with recycled aggregates. Construction and Building Materials, 18: 461-468.

Ravina, D. and P.K. Mehta, (1986) Properties of fresh concrete containing large amounts of fly ash. Cement and Concrete Research, 16(2): 227-238.

Ravindrarajah, R.S. and Tam, C.T. (1985) Properties of concrete made with crushed concrete as coarse aggregate, Magazine of concrete research, 37(130): 29-38.

Sagoe-Crentsil, K.K., Brown, T. and Taylor, A.H. (2001) Performance of concrete made with commercially produced coarse recycled concrete aggregate. Cement and Concrete Research, 31: 707-712.

Shayan, A. and $\mathrm{Xu}$, A. (2003) Performance and properties of structural concrete made with recycled concrete aggregates, ACI materials journal, 100(5):371-380.

Somna, R., Jaturapitakku, C, Chalee, W. and Rattanachu, P. (2012) Effect of the water to binder ratio and ground fly ash on properties of recycled aggregate concrete. Journal of Materials in Civil Engineering, 24(1): 16-22.

Tam, V.W.Y, Gao, X.F. and Tam, C.M. (2006) Environmental enhancement through use of recycled aggregate concrete in a two-stage mixing approach. Human and ecological risk assessment, 12:277-288.

Tangchirapat, W., Buranasing, R. and Jaturapitakku, C. (2010) Use of high fineness fly ash to improve properties of recycled aggregate concrete. Journal of Materials in Civil Engineering, 22(6): 565-571. 
Wastenet, Construction and demolition waste, (2009)

http://www.wastenet.net.au/information/streams/cons demo (accessed August 26, 2010)

Xiao, J., Li, J. and Zhang, C. (2005) Mechanical properties of recycled aggregate concrete under uniaxial loading. Cement and Concrete Research, 35: 1187-1194.

Yang, K.H., Chung, H.S. and Ashour, A.F. (2008) Influence of type and replacement level of recycled aggregates on concrete properties, ACI Materials journals, 105(3): 289-296.

Yong, P.C. and Teo, D.C.L. (2009) Utilisation of recycled aggregate as coarse aggregate in concrete. UNIMAS e-journal of civil engineering, 1(1):1-6.

Zhang, W. and Ingham, J.M. (2010) Using recycled concrete aggregates in New Zeland ready-mix concrete production, Journal of Materials in Civil Engineering, 22(5): 443-450. 
Figure 1 - Contents of RCA used in this study

Figure 2(a): Sieve analysis results of RCA

Figure 2(b): Sieve analysis results of $10 \mathrm{~mm}$ and $20 \mathrm{~mm}$ size NCA

Figure 3 Effect of RCA and fly ash on the workability of concrete

Figure 4 Effect of RCA and fly ash on compressive strength of concrete

Figure 5 Effect of RCA and fly ash on tensile strength of concrete

Figure 6 Effect of RCA and fly ash on flexural strength of concrete

Figure 7 Effect of RCA and fly ash on water absorption of concrete 


\section{Contents of RCA}

\begin{tabular}{r|c} 
Concrete & 65.30\% \\
\cline { 2 - 2 } Fines & $11.80 \%$ \\
Masonry & $11.20 \%$ \\
Bitumen & $9.90 \%$ \\
Tile/other & $1.70 \%$ \\
Wood & $0.20 \%$
\end{tabular}


J ournal of Materials in Civil Engineering. Submitted J une 12, 2012; accepted December 14, 2012; posted ahead of print December 17, 2012. doi:10.1061/(ASCE)MT.1943-5533.0000763

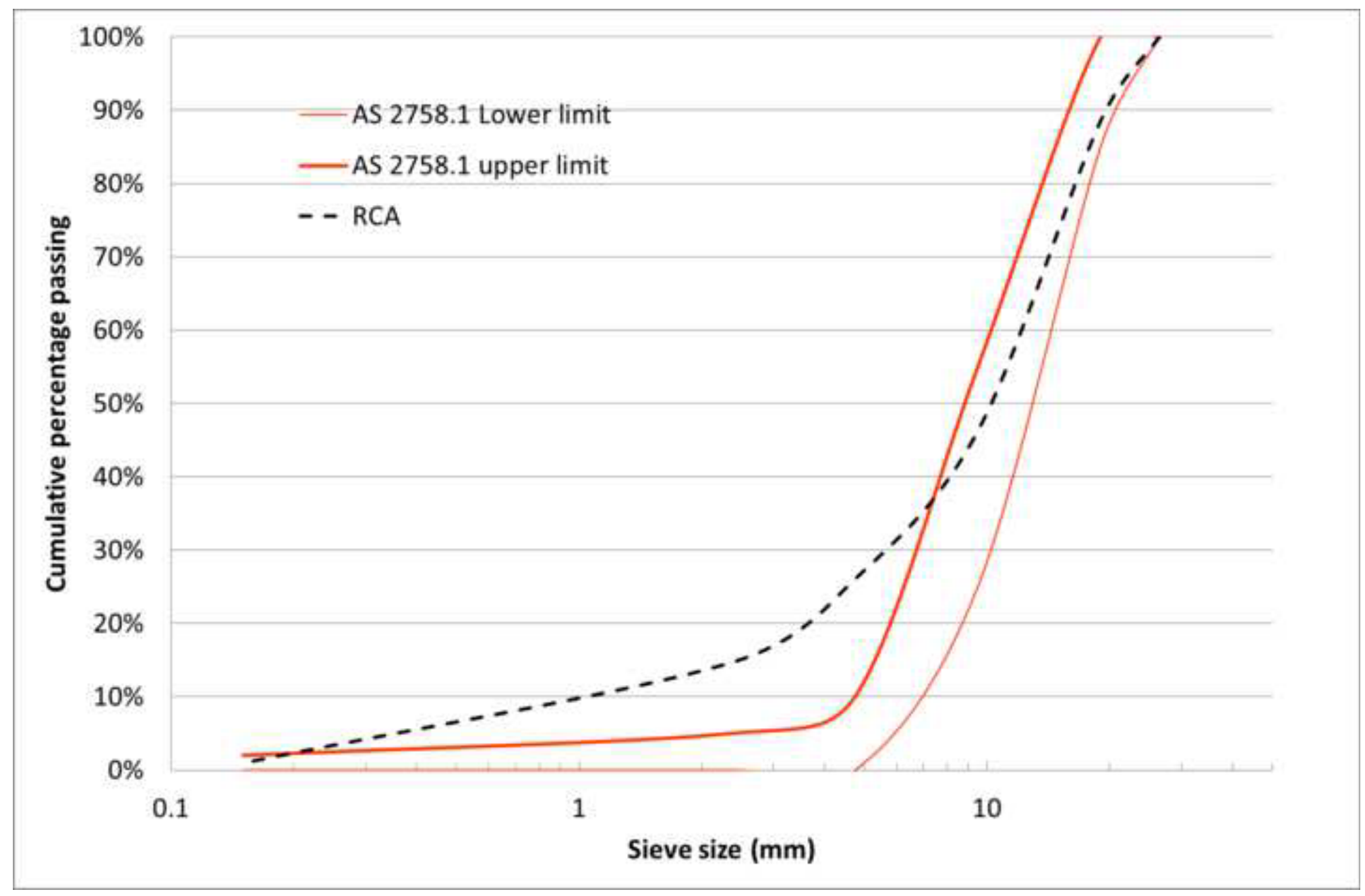




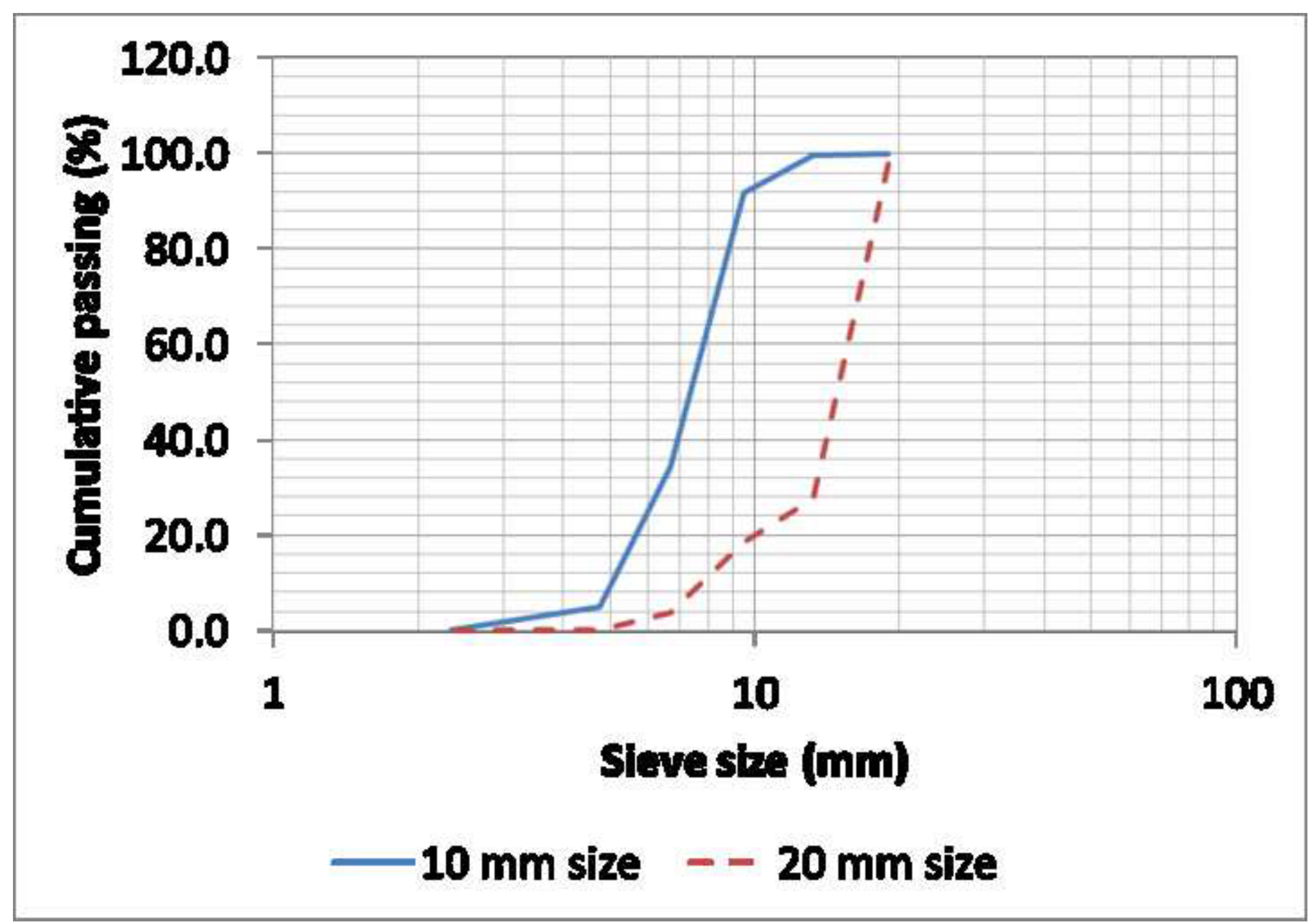


J ournal of Materials in Civil Engineering. Submitted J une 12, 2012; accepted December 14, 2012; posted ahead of print December 17, 2012. doi:10.1061/(ASCE)MT.1943-5533.0000763
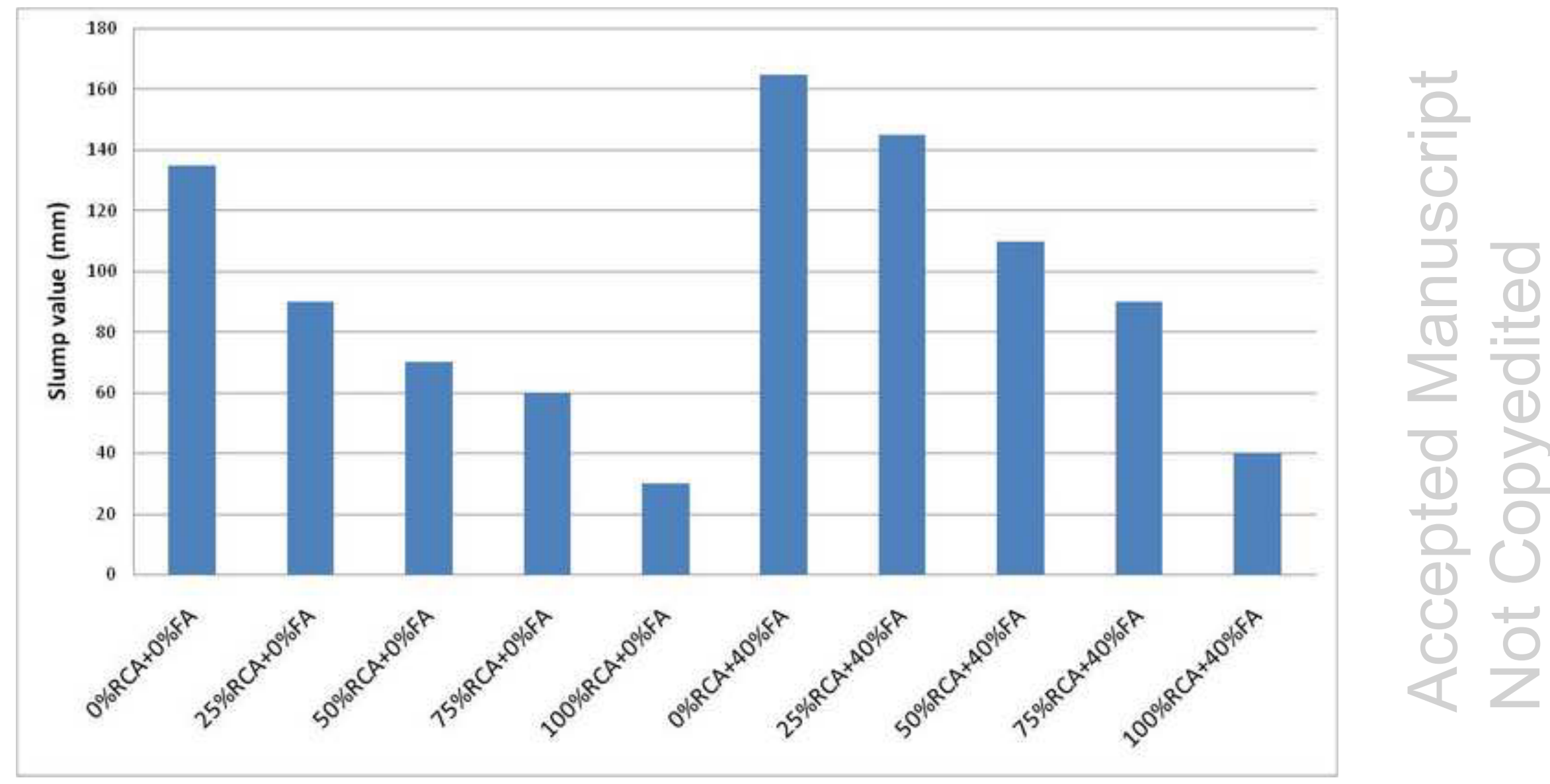


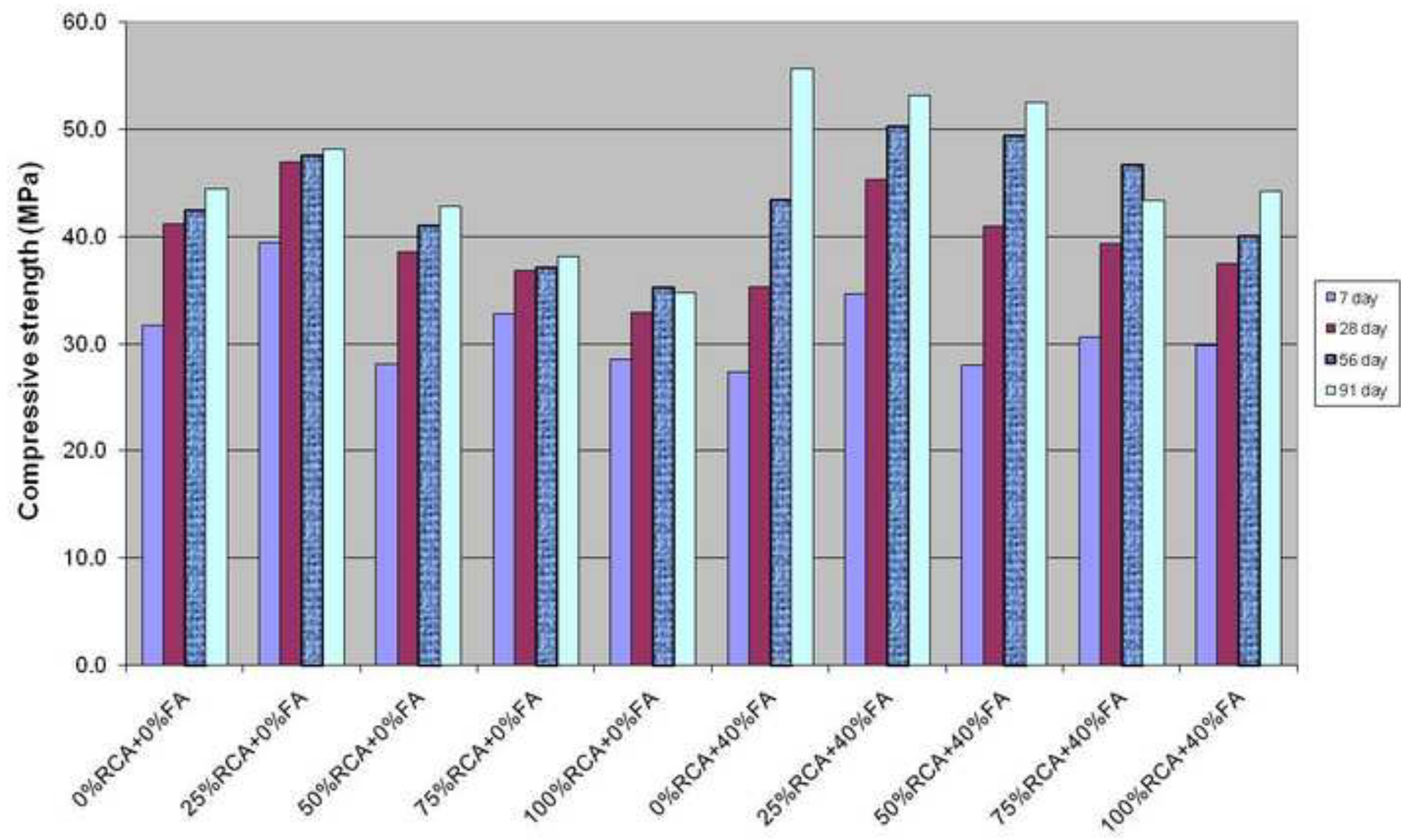



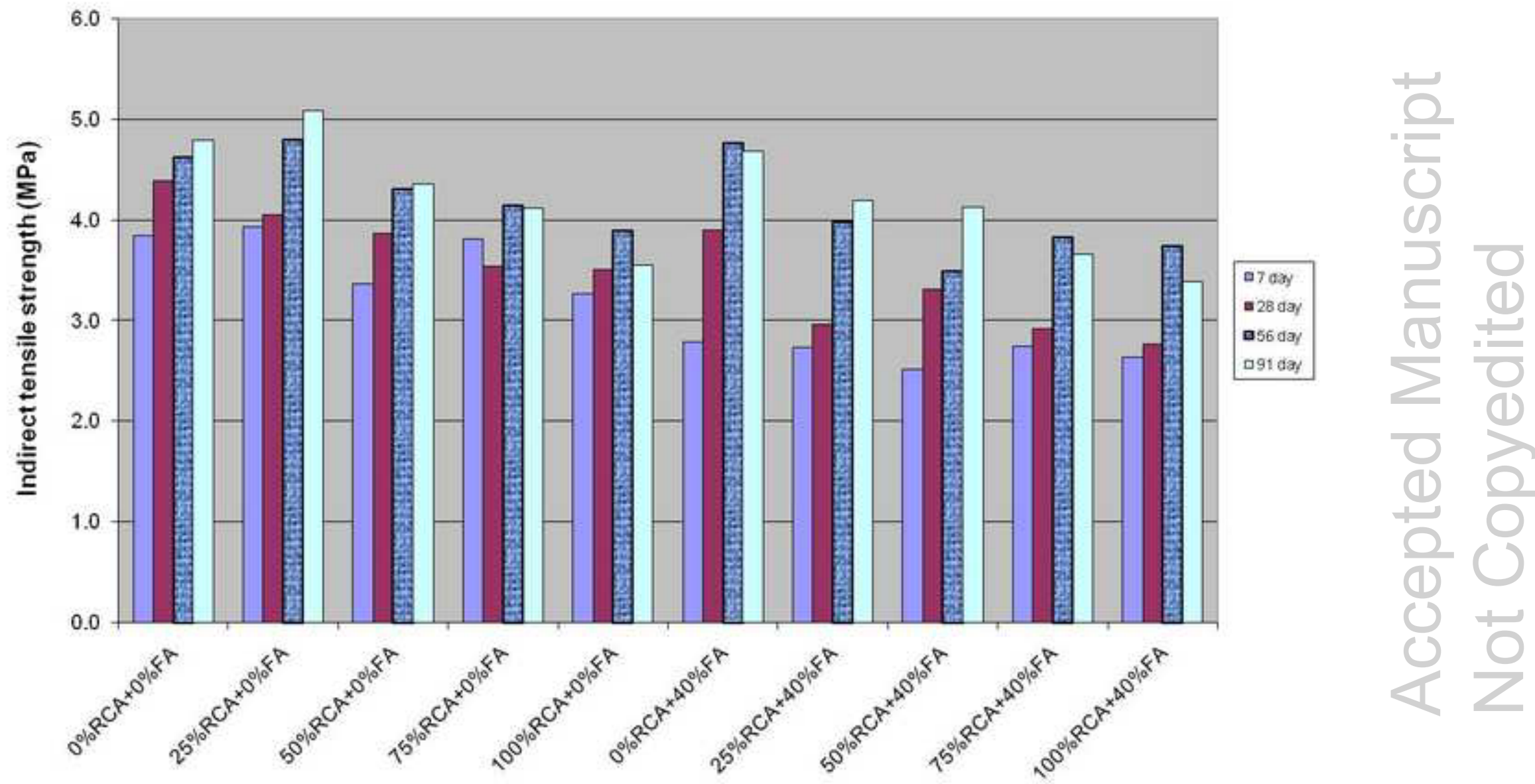


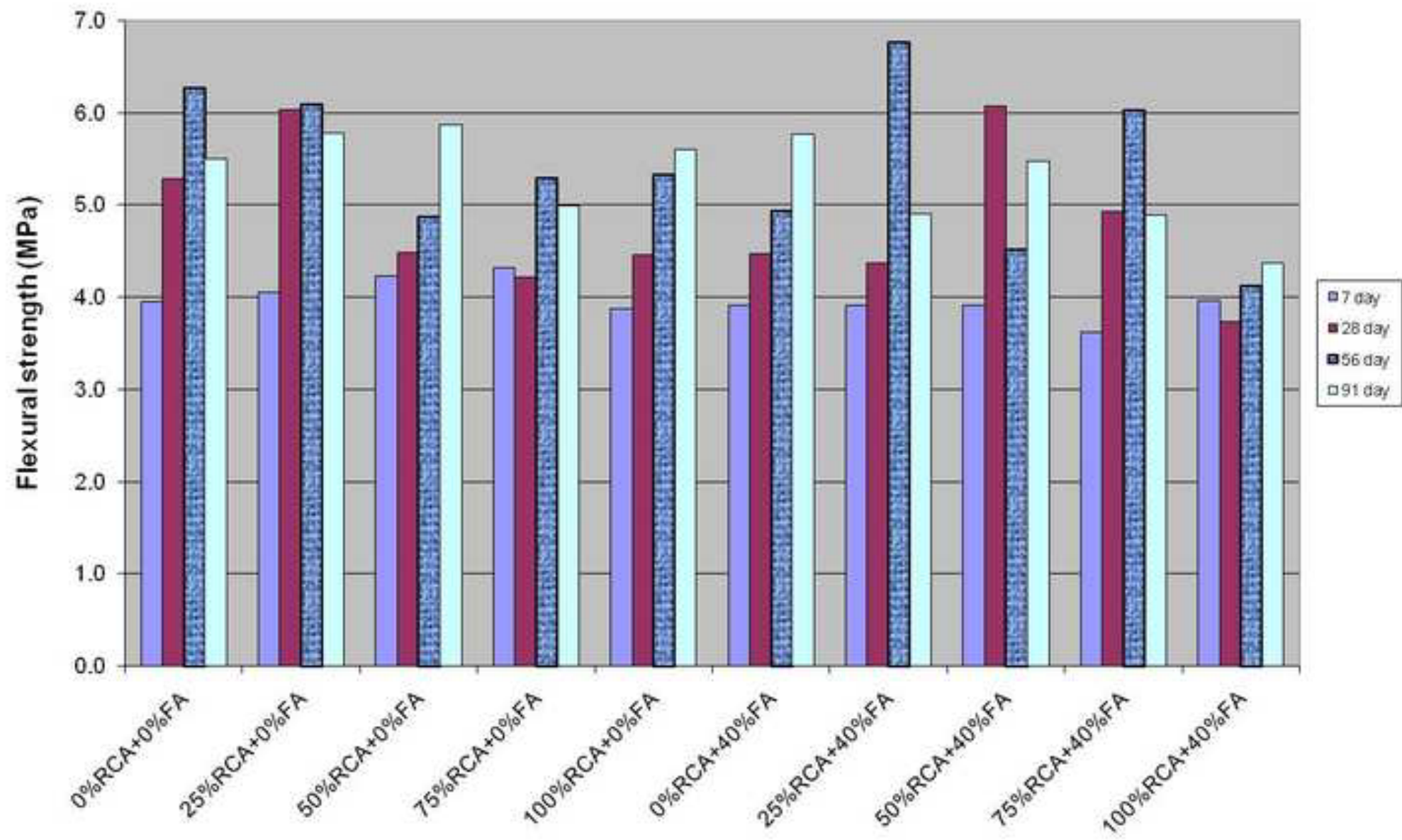



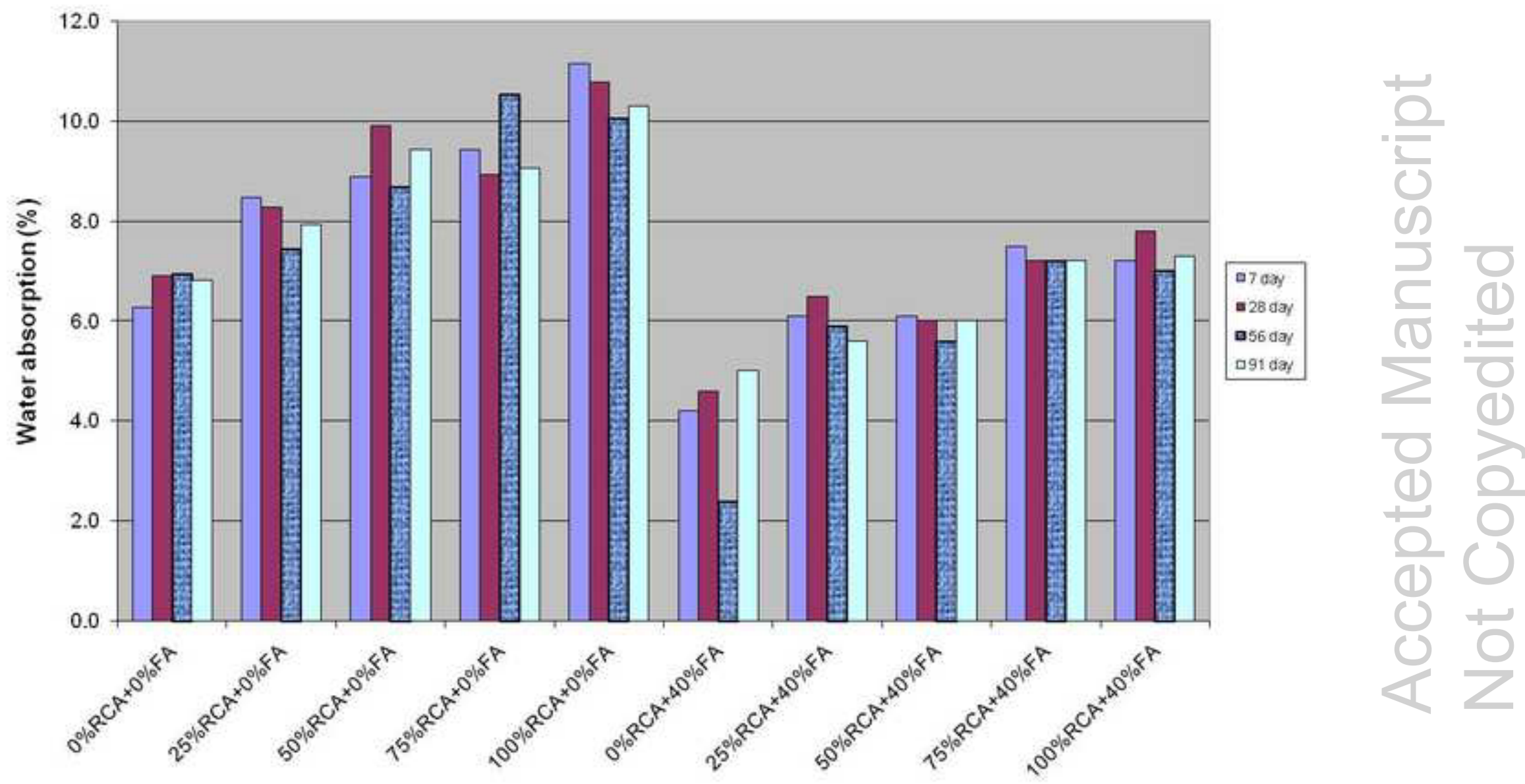
Table 1: Experimental Program

\begin{tabular}{|c|c|c|c|c|c|c|}
\hline Part & Study objectives & Series & $\mathrm{NCA}(\%)$ & RCA (\%) & $\begin{array}{l}\text { Fly ash } \\
(\%)\end{array}$ & Mix designation \\
\hline \multirow{5}{*}{ A } & \multirow{5}{*}{$\begin{array}{l}\text { Effect of RCA on the } \\
\text { properties of concrete }\end{array}$} & 1 & 100 & 0 & - & $0 \%$ RCA $+0 \%$ fly ash \\
\hline & & 2 & 75 & 25 & - & $25 \% \mathrm{RCA}+0 \%$ fly ash \\
\hline & & 3 & 50 & 50 & - & $50 \%$ RCA $+0 \%$ fly ash \\
\hline & & 4 & 25 & 75 & - & $75 \% \mathrm{RCA}+0 \%$ fly ash \\
\hline & & 5 & 0 & 100 & - & $100 \%$ RCA $+0 \%$ fly ash \\
\hline \multirow{5}{*}{ B } & \multirow{5}{*}{$\begin{array}{l}\text { Effect of fly ash on the } \\
\text { properties of concrete } \\
\text { containing RCA }\end{array}$} & 6 & 100 & 0 & 40 & $0 \% \mathrm{RCA}+40 \%$ fly ash \\
\hline & & 7 & 75 & 25 & 40 & $25 \%$ RCA $+40 \%$ fly ash \\
\hline & & 8 & 50 & 50 & 40 & $50 \%$ RCA $+40 \%$ fly ash \\
\hline & & 9 & 25 & 75 & 40 & $75 \%$ RCA $+40 \%$ fly ash \\
\hline & & 10 & 0 & 100 & 40 & $100 \%$ RCA $+40 \%$ fly ash \\
\hline
\end{tabular}

\section{Accepted Manuscript Not Copyedited}


J ournal of Materials in Civil Engineering. Submitted J une 12, 2012; accepted December 14, 2012; posted ahead of print December 17, 2012. doi:10.1061/(ASCE)MT.1943-5533.0000763

Table 2 - Chemical compositions of Portland cement and fly ash.

\begin{tabular}{|l|l|l|l|l|l|l|l|l|l|l|l|}
\hline & $\mathrm{SiO}_{2}$ & $\mathrm{Al}_{2} \mathrm{O}_{3}$ & $\mathrm{Fe}_{2} \mathrm{O}_{3}$ & $\mathrm{CaO}$ & $\mathrm{MgO}$ & $\mathrm{SO}_{3}$ & $\mathrm{~K}_{2} \mathrm{O}$ & $\mathrm{Na}_{2} \mathrm{O}$ & $\mathrm{P}_{2} \mathrm{O}_{5}$ & $\mathrm{LOI}$ & $\begin{array}{l}\mathrm{SiO}_{2}+ \\
\mathrm{Al}_{2} \mathrm{O}_{3+} \\
\mathrm{Fe}_{2} \mathrm{O}_{3}\end{array}$ \\
\hline $\begin{array}{l}\text { Cement } \\
(\%)\end{array}$ & 21.10 & 4.70 & 2.70 & 63.60 & 2.60 & 2.50 & - & 0.50 & - & 2.00 & - \\
\hline $\begin{array}{l}\text { Fly ash } \\
(\%)\end{array}$ & 50.50 & 26.57 & 13.77 & 2.13 & 1.54 & 0.41 & 0.77 & 0.45 & 1.00 & 0.60 & 90.84 \\
\hline $\begin{array}{l}\text { Class F } \\
\text { fly } \\
\text { ash* } \\
(\%)\end{array}$ & & & $\begin{array}{l}10.00 \\
\text { (Max.) }\end{array}$ & & $\begin{array}{l}5.00 \\
\text { (Max) }\end{array}$ & & & & & $\begin{array}{l}70.00 \\
\text { (Min.) }\end{array}$ \\
\hline
\end{tabular}

*ASTM C 618

\section{Accepted Manuscript} Not Copyedited 
J ournal of Materials in Civil Engineering. Submitted J une 12, 2012; accepted December 14, 2012; posted ahead of print December 17, 2012. doi:10.1061/(ASCE)MT.1943-5533.0000763

Table 3 - Properties of Natural and Recycled aggregates

\begin{tabular}{|l|l|l|}
\hline Aggregate Type & Particle Density $\left(\mathrm{kg} / \mathrm{m}^{3}\right)$ & Water Absorption $(\%)$ \\
\hline Natural Coarse aggregate & 2758 & 0.9 \\
\hline Natural Fine aggregate & 2613 & 0.7 \\
\hline Recycled coarse aggregate (RCA) & 2127 & 6.4 \\
\hline Fine portion of RCA & 2103 & 9.1 \\
\hline
\end{tabular}

\section{Accepted Manuscript Not Copyedited}


Table 4 - Mix proportions

\begin{tabular}{|c|c|c|c|c|c|c|}
\hline \multirow[t]{2}{*}{ Mix designation } & \multicolumn{6}{|c|}{ In $\mathrm{kg} / \mathrm{m}^{3}$} \\
\hline & Water & Cement & $\begin{array}{l}\text { Fly } \\
\text { ash }\end{array}$ & $\begin{array}{l}\text { Fine } \\
\text { aggregate }\end{array}$ & $\mathrm{NCA}$ & RCA \\
\hline $0 \%$ RCA $+0 \%$ fly ash & 241 & 536 & 0 & 619 & 1010 & 0 \\
\hline $25 \%$ RCA $+0 \%$ fly ash & 241 & 536 & 0 & 619 & 758 & 253 \\
\hline $50 \%$ RCA $+0 \%$ fly ash & 241 & 536 & 0 & 619 & 535 & 535 \\
\hline $75 \%$ RCA $+0 \%$ fly ash & 241 & 536 & 0 & 619 & 253 & 758 \\
\hline $100 \%$ RCA $+0 \%$ fly ash & 241 & 536 & 0 & 619 & 0 & 1010 \\
\hline $0 \%$ RCA $+40 \%$ fly ash & 241 & 321 & 215 & 619 & 1010 & 0 \\
\hline $25 \%$ RCA $+40 \%$ fly ash & 241 & 321 & 215 & 619 & 758 & 253 \\
\hline $50 \%$ RCA $+40 \%$ fly ash & 241 & 321 & 215 & 619 & 535 & 535 \\
\hline $75 \%$ RCA $+40 \%$ fly ash & 241 & 321 & 215 & 619 & 253 & 758 \\
\hline $100 \%$ RCA $+40 \%$ fly ash & 241 & 321 & 215 & 619 & 0 & 1010 \\
\hline
\end{tabular}

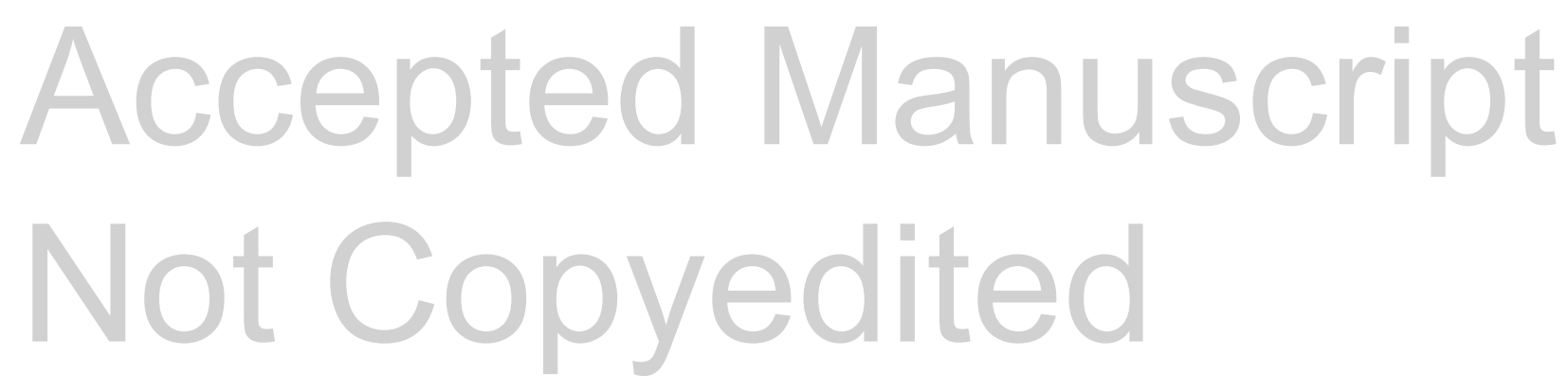


Table 5 - Relationship between splitting tensile strength and compressive strength of concrete containing RCA and fly ash

\begin{tabular}{|l|c|c|}
\hline Mix designation & $\begin{array}{l}\text { Mean 28 day compressive } \\
\text { strength }(\mathrm{MPa})\end{array}$ & $\begin{array}{l}\text { Percentage of splitting } \\
\text { tensile } \\
\text { compressive strength (\%) }\end{array}$ \\
\hline $0 \%$ RCA $+0 \%$ fly ash & 41.2 & 8.59 \\
\hline $25 \%$ RCA $+0 \%$ fly ash & 46.9 & 6.97 \\
\hline $50 \%$ RCA $+0 \%$ fly ash & 38.6 & 8.07 \\
\hline $75 \%$ RCA $+0 \%$ fly ash & 36.8 & 7.75 \\
\hline $100 \%$ RCA $+0 \%$ fly ash & 32.9 & 8.60 \\
\hline $0 \%$ RCA $+40 \%$ fly ash & 35.3 & 11.05 \\
\hline $25 \%$ RCA $+40 \%$ fly ash & 45.3 & 6.53 \\
\hline $50 \%$ RCA $+40 \%$ fly ash & 41.0 & 8.07 \\
\hline $75 \%$ RCA $+40 \%$ fly ash & 39.3 & 7.43 \\
\hline $100 \%$ RCA $+40 \%$ fly ash & 37.5 & 7.39 \\
\hline
\end{tabular}

\section{Accepted Manuscript Not Copyedited}

